\title{
Spatiotemporal pattern of wild boar rooting in a Central European dry oak forest
}

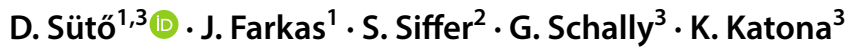

Received: 25 June 2019 / Revised: 13 November 2019 / Accepted: 28 November 2019 / Published online: 6 December 2019

(c) The Author(s) 2019

\begin{abstract}
Wild boar (Sus scrofa) density has significantly increased worldwide. In Europe, oak acorns are basic diet items for the species. However, regeneration of temperate oak forests has become excessively low. Thus, better understanding of the patterns and dynamics of wild boar rooting and the spatiotemporal relationship between the acorn density and the rooting has special importance. In our study, the acorn density, the presence and intensity of the rooting were measured monthly in a 28-ha oak forest stand between 2016 October and 2019 April. Study site was divided to $400 \mathrm{~m}^{2}$ grid cells to investigate the spatiotemporal patterns of the rooting. Comparing the acorn densities, we stated that in the first 2 years, but not in the third one, the oaks were masting. During the acorn-rich periods (October-April), significant inter-annual differences were found in the proportions of the disturbed area between the non-mast and the other two mast years. Throughout our observations, 9.12\% of the cells stayed undisturbed. On average, in $12.59 \%$ of the cells new rooted patches appeared, and $15.6 \%$ of them was repeatedly disturbed. Rooting were mainly litter disturbances in $71.75 \%$ of cases. Throughout acorn fall periods (September-November), the most intensively rooted sites were the poorest in acorns, while the unrooted sites were the richest. Our results demonstrate that wild boars have a great effect on acorn density and on the whole forest by rooting almost the entire ground surface at least once, but also the masting of the oaks has a crucial role in their rooting dynamics.
\end{abstract}

Keywords Acorn · Mast year $\cdot$ Sus scrofa $\cdot$ Ungulate impact $\cdot$ Game damage $\cdot$ Forest regeneration

\section{Introduction}

Nowadays, the regeneration of the temperate oak (Quercus spp.) forests has become excessively weak on the Northern Hemisphere, often reflected by the missing or scarce regeneration layer (Brudvig 2008; Katona et al. 2013; Leonardsson et al. 2015). This fact raises a number of serious economic and conservation issues (Brudvig 2008; Schelhaas et al. 2012; de Rigo et al. 2016; Eaton et al. 2016).

Communicated by Claus Bässler.

D. Sütő

suto.david@mkk.szie.hu

1 Department of Systematic Zoology and Ecology, Eötvös Loránd University, Pázmány Péter sétány 1/C, Budapest 1117, Hungary

2 Forestry Corporation of Bálint-hegy, Kossuth utca 9, Zánka 8251, Hungary

3 Institute for Wildlife Conservation, Szent István University, Páter Károly utca 1, Gödöllő 2100, Hungary
The outstanding biological importance of the oak forests is unquestionable; they act as important biodiversity hot spots and provide habitat for a great number of species of insects, fungi, bats and other organisms including several threatened species (Bobiec et al. 2011; Leonardsson et al. 2015; de Rigo et al. 2016; Eaton et al. 2016).

During the whole regeneration cycle of the woody plant species, seedlings represent one of the most vulnerable phases. The mortality rate of the seedlings can be particularly high, and they are susceptible to herbivore browsing and other biotic and abiotic circumstances (Gómez and Hódar 2008; Perea and Gil 2014).

The appropriate quantity and quality of seedlings, however, largely depends on the processes in the previous stages of the regeneration. The acorn production and the germination of the seeds can have a critical influence on the oak regeneration (Gómez and Hódar 2008; Perea and Gil 2014; Massei et al. 2015; Kamler et al. 2016). Additionally, seed predators also have a significant role in decelerating the regeneration process. The most typical forest seed predators include different birds, rodents and ungulates, especially 
the wild boar (Sus scrofa) (van Ginkel et al. 2013; Kamler et al. 2016).

The survival of the oak acorns is driven by many factors after falling from the tree. Apart from predation, they can often be ruined by infections and other abiotic effects (van Ginkel et al. 2013). But the primer determinant of their survival chance is the natural density of the oak acorns, which is enhanced by periodically occurring mast years (Sork 1993; Bisi et al. 2018; Bogdziewicz et al. 2018). According to the studies by Cutini et al. (2013) and Nováková and Štípek (2011), there is a strong positive correlation between the reproductive success of wild boar and acorn production. The tree can defend against its seed predators by pulsing the availability of resources-the acorns - creating lagged responses in the successive trophic levels. This can allow a better survival for the acorns in a mast year along with a decreased seed predator population (Haas and Heske 2005; Bisi et al. 2018).

In the recent decades, the number of wild boars has significantly increased worldwide. Simultaneously, the number of conflicts related to the species has also escalated (Massei and Genov 2004; Barrios-Garcia and Ballari 2012; Kamler et al. 2016; Bongi et al. 2017). Wild boar is an opportunistic omnivore species, although $90 \%$ of its diet consists of plant materials (Massei and Genov 2004; Barrios-Garcia and Ballari 2012; Bongi et al. 2017; Katona and Heltai 2018).

The most important food components are the large fruits and seeds of high energy content. In the temperate zone of Europe, the acorn of oak and beech can constitute as such food items (Groot Bruinderink and Hazebroek 1996; Massei and Genov 2004; Ballari and Barrios-García 2014; Kamler et al. 2016; Bisi et al. 2018). The acorn means the main diet component from autumn to spring, and it is not uncommon that the stomach content of wild boars consists of acorns around 90\% in mast years (Groot Bruinderink et al. 1994; Bongi et al. 2017). Other studies also showed that acorn is the preferred food source for wild boars even if other food sources were available, e.g. anthropogenic or agricultural ones (Katona and Heltai 2018).

Acorn and other below-ground materials can be found and ingested through the rooting of the litter and the soil surface; therefore, rooting is the obvious sign of the feeding behaviour of wild boar (Welander 2000). Wild boars can consume a significant amount of oak affecting the regeneration of oak species, but by their rooting they also drive the changes in the composition of the above-ground herbaceous layer (Horčičková et al. 2019). Eventually, they can impede the regeneration of the forest and alter succession process and change their environment (Groot Bruinderink and Hazebroek 1996; Massei and Genov 2004; Gómez and Hódar 2008; Barrios-Garcia and Ballari 2012; van Ginkel et al. 2013; Kamler et al. 2016; Bongi et al. 2017; Ramirez et al. 2018). Based on this, wild boar can be considered as an ecosystem engineer, being able to profoundly change directly or indirectly the characteristics of the habitat and the availability of resources (Barrios-Garcia and Ballari 2012; Mráz and Katona 2014).

Some previous studies have already revealed the patterns of the rooting and the environmental factors driving them (Groot Bruinderink et al. 1994; Welander 2000; Bisi et al. 2018). The temporal patterns are relatively better described (Dardaillon 1986; Groot Bruinderink and Hazebroek 1996; Ballari and Barrios-García 2014; Kamler et al. 2016). However, we have much less knowledge about the spatial distribution patterns of the rooting and its dynamics along the year, particularly in temperate oak forests in periods with different intensities of mast-fall. Therefore, our questions were:

1. What is the proportion of the rooted areas of an oak forest in different periods of the year of different acorn availability?

2. How does the distribution of the rooted areas change from month to month in mast and non-mast years?

3. Is there any spatial relationship between the rooting intensity and acorn density?

\section{Materials and methods}

\section{Study area}

The study area is located in Hungary, on the north of the lake Balaton, in Veszprém county, in the region of Zánka village $\left(46^{\circ} 52^{\prime} 32.8^{\prime \prime} \mathrm{N} 17^{\circ} 38^{\prime} 57.4^{\prime \prime} \mathrm{E}\right)$. The area is in the dryer parts of the humid continental climatic region, with an average annual temperature between 10.2 and $10.5^{\circ} \mathrm{C}$. The annual average rainfall is between 600 and $640 \mathrm{~mm}$. The bedrock of the area is dominated by new red sandstone; meanwhile, the soil can mainly be characterized by red clay rendzina.

Our investigation was carried out in a private dry Turkeysessile oak forest (Fraxino orno-Quercetum cerridis) managed by Hercegerdô Forest Corporation. The study area was a 28-ha forest unit surrounded directly by similar oak forests. Agricultural fields, dominated by vineyards, can be found in less than $500 \mathrm{~m}$ afar in the north-northeast neighbourhood. The forest unit had a quite even Turkey-sessile oak abundance (cca. $48 \%$ and 52\% among oak trees, respectively). The forest stand is fairly mixed, and cca. $30 \%$ of the tree population is subdominant tree species, such as flowering ash (Fraxinus ornus), field maple (Acer campestre), checker tree (Sorbus torminalis) and common hornbeam (Carpinus betulus). The forest is managed by single tree selection and group selection patch cuts since 1994. The main product of the area is firewood. Mitigation of the oak regeneration due to acorn predation by wild boar is considered as a serious 
problem by the local forest managers, reflected in the fenced small gaps, established by previous timber utilization, to enhance the development of acorns and defend the emerging saplings.

The population density of the ungulate species occurring in the area, based on the reported hunting bags in Veszprém county, is cca. 2.8 shot ind./100 ha for wild boar, 1.4 ind./100 ha for red deer (Cervus elaphus), 1.1 ind./100 ha for roe deer (Capreolus capreolus), and 0.2 ind./100 ha for fallow deer (Dama dama) (Csányi et al. 2018).

\section{Field data collection}

After we chose our study area, we recorded several border points with a GPS device (GARMIN eTrex 20). The data for the monitoring have been collected once in about every 35 days between 2016 October and 2019 April. We designated 12 transects parallel with each other and the southern border of the area. All the transects were about $2 \mathrm{~m}$ wide, 500 to $1400 \mathrm{~m}$ long and $20 \mathrm{~m}$ from each other. On these transects, one sampling point per every $100 \mathrm{~m}$ was appointed; altogether, we obtained 118 sampling points (except in 2016 October when there were 122 and in 2017 September when there were 71, due to bad weather conditions) (Fig. 1).
On all these sampling points, we measured the density of acorns by oak species in a $1 \mathrm{~m} \times 1 \mathrm{~m}$ quadrant. During this examination, we moved over the litter at the sampling points to find and count all the acorns. Then we arranged the litter back to decrease our disturbing effect. Along the full length of the transects, we also recorded by the GPS device the locations of all patches rooted by wild boar. When our transects crossed the rooted areas, we recorded an entry and an exit point. We considered a patch as rooted by wild boar when the disturbed site heavily differed from the undisturbed surroundings. Wild boar rooting often means the disturbance of the top of the soil layer. Thereby litter and soil can mingle. The size of the rooted patch usually varies between 1 and $100 \mathrm{~m}^{2}$, and the disturbed soil layer can be up to 20 to $40 \mathrm{~cm}$ deep.

During our data collection, we categorized these disturbed areas by the intensity of the rooting into three main categories:

- Litter disturbances (further on LD): Only the litter was slightly tossed and moved over.

- Upper soil disturbances (further on USD): More intensively disturbed patches, where both the litter and soil were rooted and slightly agitated. Only the top $5 \mathrm{~cm}$ of the soil was disturbed.

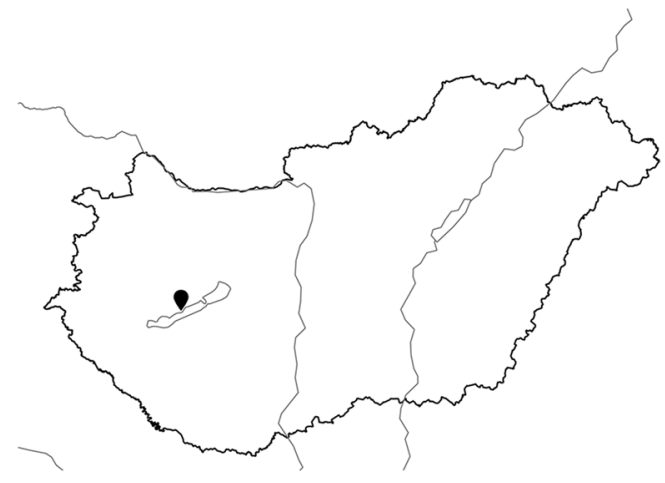

1:2 872222
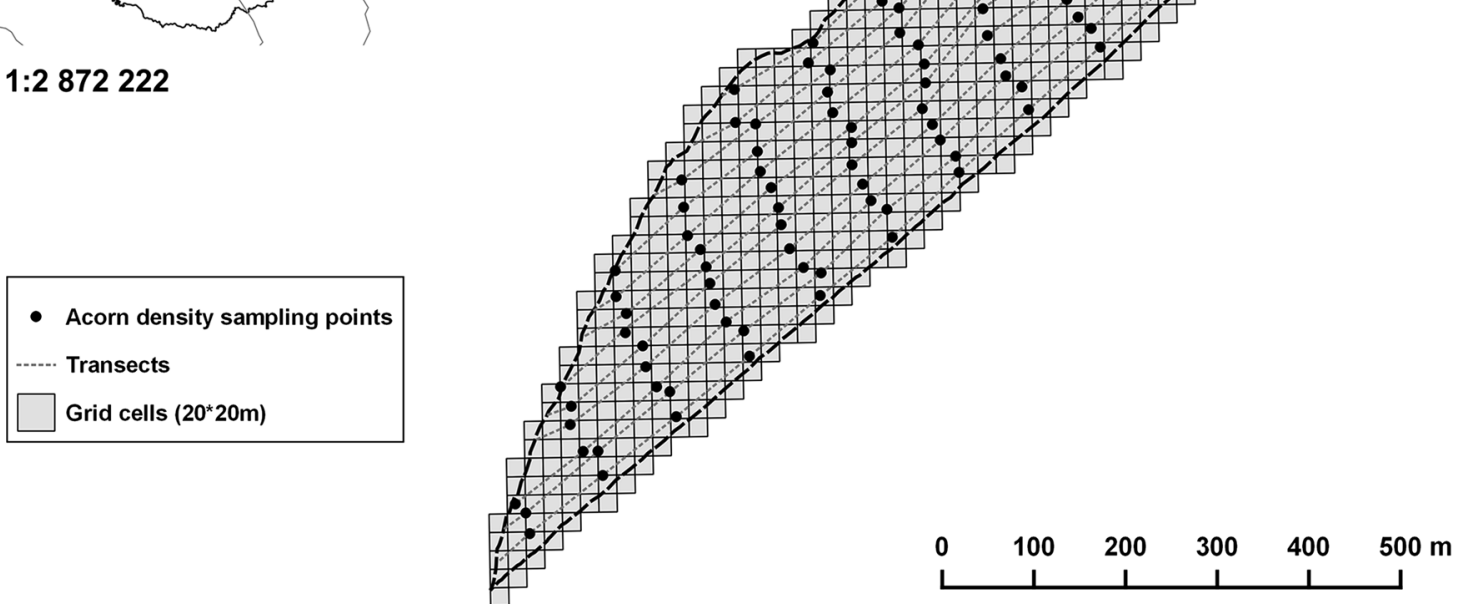

Fig. 1 Location of the study site (top left), grid cells and the design of the acorn density sampling points and transects (right) 
- Deeper soil disturbances (further on DSD): When the rooting was relatively intensive and disturbed the soil deeper than $5 \mathrm{~cm}$.

\section{Data analysis}

The data have been processed and analysed in Microsoft Office Excel 365, StatSoft Statistica 12 and in QGIS 2.18 Las Palmas (in HD72/EOV (EPSG: 23700) coordinate reference system).

We draw the borders of our study area from the collected points, and then we converted it to a polygon. A new layer has been added which was divided to $20 \mathrm{~m}$ by $20-400 \mathrm{~m}^{2}$ cells. We kept the cells which were on our polygon-therefore within the borderline of the study area-that gave us 702 cells of $400 \mathrm{~m}^{2}$, altogether 28.08 ha. The entry and exit points have been sorted by the intensity of the rooting and then converted to litter, upper soil or deeper soil disturbance lines by linking the points. We analysed how these newly drawn lines distributed over the study area by marking the cells if there was any rooting in them. Although, it is important to mention, that it is some kind of overestimation of the rooted surface as the recognition of rooting along our transect did not mean that the whole- $400 \mathrm{~m}^{2}$ - sample unit, the full cell was disturbed. We were also able to separately mark the cells by the different kind of rooting types that they contained at a given time. In this way, we investigated the intensity of area use by wild boar population (its impact on the habitat) and not the home range use of single individuals.

We divided the study to different temporal sample units in two different ways. On the one hand, we appointed the acorn fall period, which was between 2016 October to November, 2017 September to November and 2018 September to November, when we expected the oak acorns to fall from the trees. On the other hand, we also appointed an acornrich and an acorn-weak period. The acorn-rich period was between October and April in every study year, when we expected that there are acorns available on the ground to the seed predators before germinating and becoming a seedling or ruined and disappearing. The acorn-weak period meant the rest of the study interval. We analysed the changes of the acorn density and wild boar rooting at the study site in the above-mentioned periods. We observed the inter-annual effects and determined the mast and non-mast years.

\section{Statistics}

We compared the acorn density, the proportion of the rooted cells, the proportion of rooting categories based on the temporal within-cell changes of disturbances between consecutive assessments-if the rooting in the cell appeared, remained, disappeared or the cell was repeatedly undisturbed - and the proportion of the classes of different rooting intensities between the acorn fall versus the non-fall and the acorn-rich versus the acorn-weak periods with Mann-Whitney $U$ test. Kruskal-Wallis tests with Dunn's post hoc tests were applied to measure the significant differences among the values of all these above-mentioned variables among years or their sub-intervals. Our acorn density datasets showed non-normal distribution by Shapiro-Wilk $W$ test ( $W=0.19$ to 0.67 and $P<0.0001$ for all the measured periods) and in other cases typically formed by nominal and categorical variables. That was the reason to rely on nonparametric statistical tests during the comparisons.

We investigated how the proportions of the different kinds of earlier mentioned rooting intensity types changed during these time intervals and how this intensity interfered with the acorn density. In cases when different rooting types were revealed in the same cell (see as combined rooting categories later, e.g. LD+USD+DSD), we classified it to the highest intensity type based on what the cell contained. We categorized the acorn densities from different assessments separately; first we identified the sampling points with outlying high acorn density by the ROUT method (Motulsky and Brown 2006) $(Q=0.1 \%)$ in the case of every assessment. This gave us the upper acorn density category. Then if it was possible, we split up the rest to two other groups (middle and lower categories) with Jenks optimization method (Jenks 1967). To analyse the distribution of the different rooting intensity types along with the acorn density categories, Pearson or maximum likelihood ratio Chi square was used.

\section{Results}

\section{Temporal pattern of the oak acorn density}

The average acorn density throughout the study was $2.75 \pm 7.81 \mathrm{pcs} . / \mathrm{m}^{2}$. However, if broken down to different periods, we got a more diverse picture. Figure 2 shows that our data were pretty skewed, which means in a large number of cases the oak acorn density was fairly low or even there was no acorn at all at the sampling points.

Considering the acorn fall periods of all 3 years, the average density was $5.86 \pm 11.81 \mathrm{pcs} . / \mathrm{m}^{2}$ (Mdn (median): 1.00 , IQR (interquartile): 5.86), while in the non-fall periods it was $1.54 \pm 5.02 \mathrm{pcs} . / \mathrm{m}^{2}$ (Mdn: 0.00, IQR: 1 ). However, the difference was not significant $(U=22,258.5, p=0.52$ ).

But if we examine the inter-annual effects on the acorn density, the different acorn fall periods varied. The medians were $2.5 \mathrm{pcs} . / \mathrm{m}^{2}$ (IQR:7) in $2016,5 \mathrm{pcs} . / \mathrm{m}^{2}$ (IQR:13) in 2017 and $0 \mathrm{pcs} . / \mathrm{m}^{2}$ (IQR:0) in 2018 autumn. We found that the acorn density significantly differed among the annual acorn fall periods ( $\mathrm{KW}=215.9, p<0.001$ ); in 2018 autumn, the acorn density was lower than in the two previous acorn fall periods (Dunn's post hoc test: $p<0.001$ ). Through the 
Fig. 2 Measured acorn densities at sampling points during the study interval. Acorn symbols indicate the acorn fall periods, while snowflake symbols indicate when the study site was covered by snow during the sampling. The breaks on the horizontal axis refer to gaps in data collection

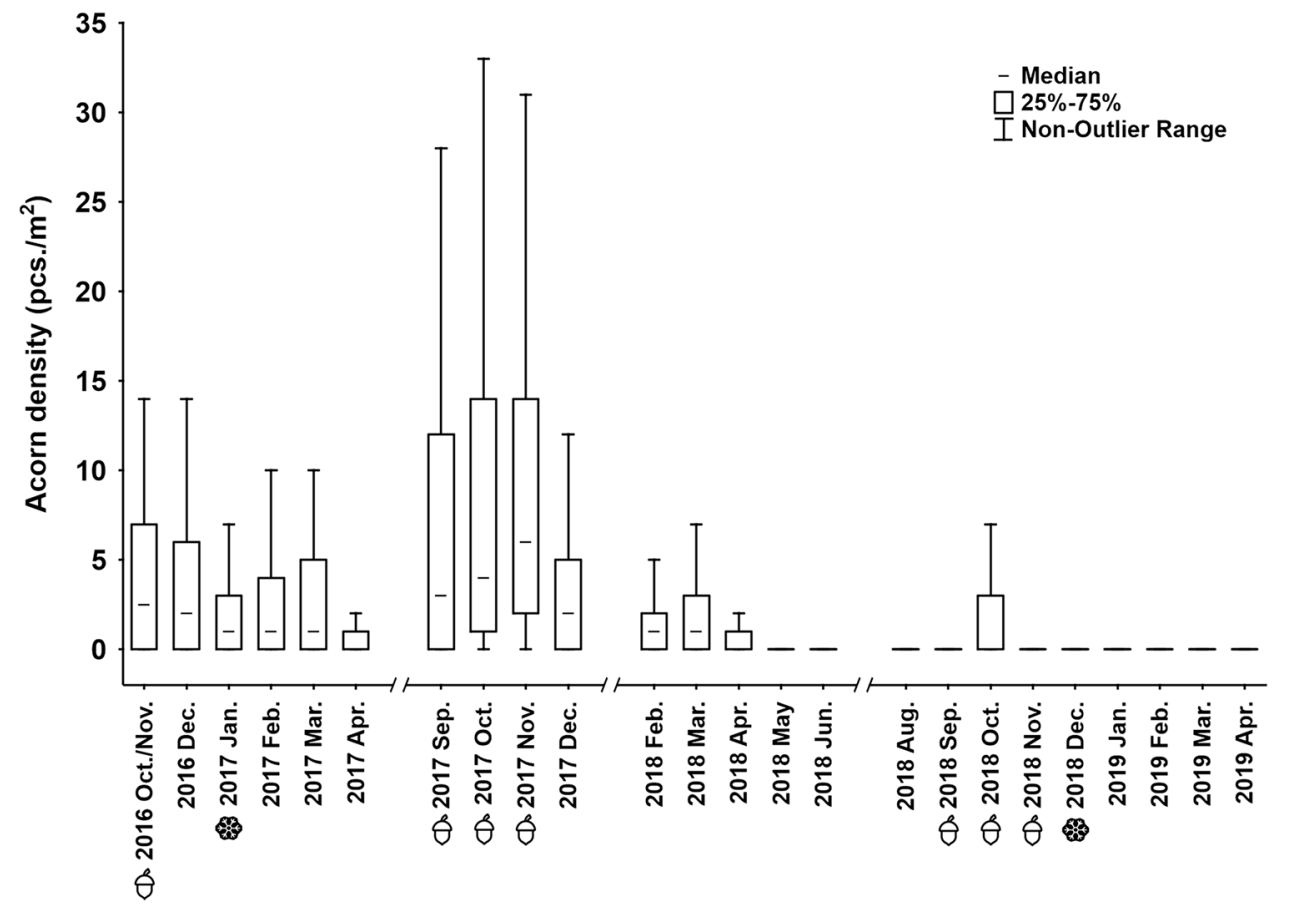

study, the highest acorn density median was registered in 2017 November (6.00 pcs./m², IQR: 11.75). Therefore, we can assume that in 2016 and 2017 the oaks were masting, but not in 2018.

During the three investigated acorn-rich periods, the average acorn density was $2.96 \pm 7.27 \mathrm{pcs} . / \mathrm{m}^{2}$ (Mdn: 0.00 , IQR:3) and was higher $(U=431,434.5, p<0.001)$ by contrast in the acorn-weak periods, when it was $1.88 \pm 9.71 \mathrm{pcs}$./ $\mathrm{m}^{2}$ (Mdn: 0.00, IQR:0). If we observe the annual acorn-rich periods, the medians of the acorn density were $1.00 \mathrm{pcs} . / \mathrm{m}^{2}$ (IQR:4) in the first, $2.00 \mathrm{pcs} . / \mathrm{m}^{2}$ (IQR:5) in the second and $0.00 \mathrm{pcs} . / \mathrm{m}^{2}$ (IQR:0) in the third year. The patterns were quite similar to the acorn fall periods, and the density was significantly lower in the third acorn-rich period than in the previous two (KW $=471.71, p<0.001$; Dunn's post hoc test: $p<0.001)$.

\section{Total wild boar rooting disturbance of the study area}

Through the spell of the study, the average proportion of the disturbed cells was $28.11 \pm 22.01 \%$. The maximum proportion of disturbed area was $80.31 \%$ and was registered in 2018 February, while the minimum was $0 \%$ and was observed in 2018 December (Fig. 3).

We could not reveal any significant difference in rooting between the acorn fall (mean \pm SD: $24.35 \pm 13.37 \%$; Mdn: $25.39 \%$ ) versus non-fall (mean \pm SD: $31.79 \pm 23.27 \%$; Mdn: $31.95 \%)(U=46.5, p=0.26)$ and the acorn-rich (mean $\pm \mathrm{SD}$ : $29.49 \pm 24.61 \%$; Mdn: $29.81 \%)$ versus acorn-weak periods (mean \pm SD: $24.35 \pm 13.37 \%$; Mdn: $25.39 \%)$ ( $U=64, p=0.91$ ).

But during the acorn-rich periods, the average proportions of the disturbed area were the following: chronologically: $34.5 \pm 14.12 \%$ (Mdn: $31.53 \%$ ), $52.57 \pm 21.94 \%$ (Mdn: $54.21 \%$ ) and $5.42 \pm 4.11 \%$ (Mdn: $5.28 \%$ ). This inter-annual difference was significant between the third and the other two acorn-rich periods (KW $=13.46, p=0.001$; Dunn post hoc test: $p<0.05$ ). The inter-annual changes of rooting were similar to the yearly pattern of the acorn density.

\section{The spatiotemporal dynamics of the wild boar rooting}

Throughout our observations $9.12 \%$ of the cells stayed undisturbed all along while we monitored the study area. Meanwhile, the highest disturbance frequency of a cell was $79.17 \%$. The average disturbance frequency was $30.15 \pm 17.75 \%$. During our study, on average in $12.59 \pm 9.58 \%$ (Mdn: $10.54 \%$ ) of the cells new rooted patches appeared from one sampling to the next one ("appeared"), $15.6 \pm 17.21 \%$ (Mdn: $7.83 \%$ ) was repeatedly "disturbed", from $13.22 \pm 11.05 \%$ (Mdn: $9.97 \%$ ) of the cells the previously rooted patches "disappeared" and $58.59 \pm 25.13 \%$ (Mdn: 54.84\%) remained "undisturbed" (Fig. 4). The proportion of the "undisturbed" cells was significantly higher than that of the others (KW $=44.62, p<0.001$; Dunn's post hoc test: $p<0.001)$.

During the acorn-rich period of the non-mast year (2018-2019), there were significantly fewer "appeared" 


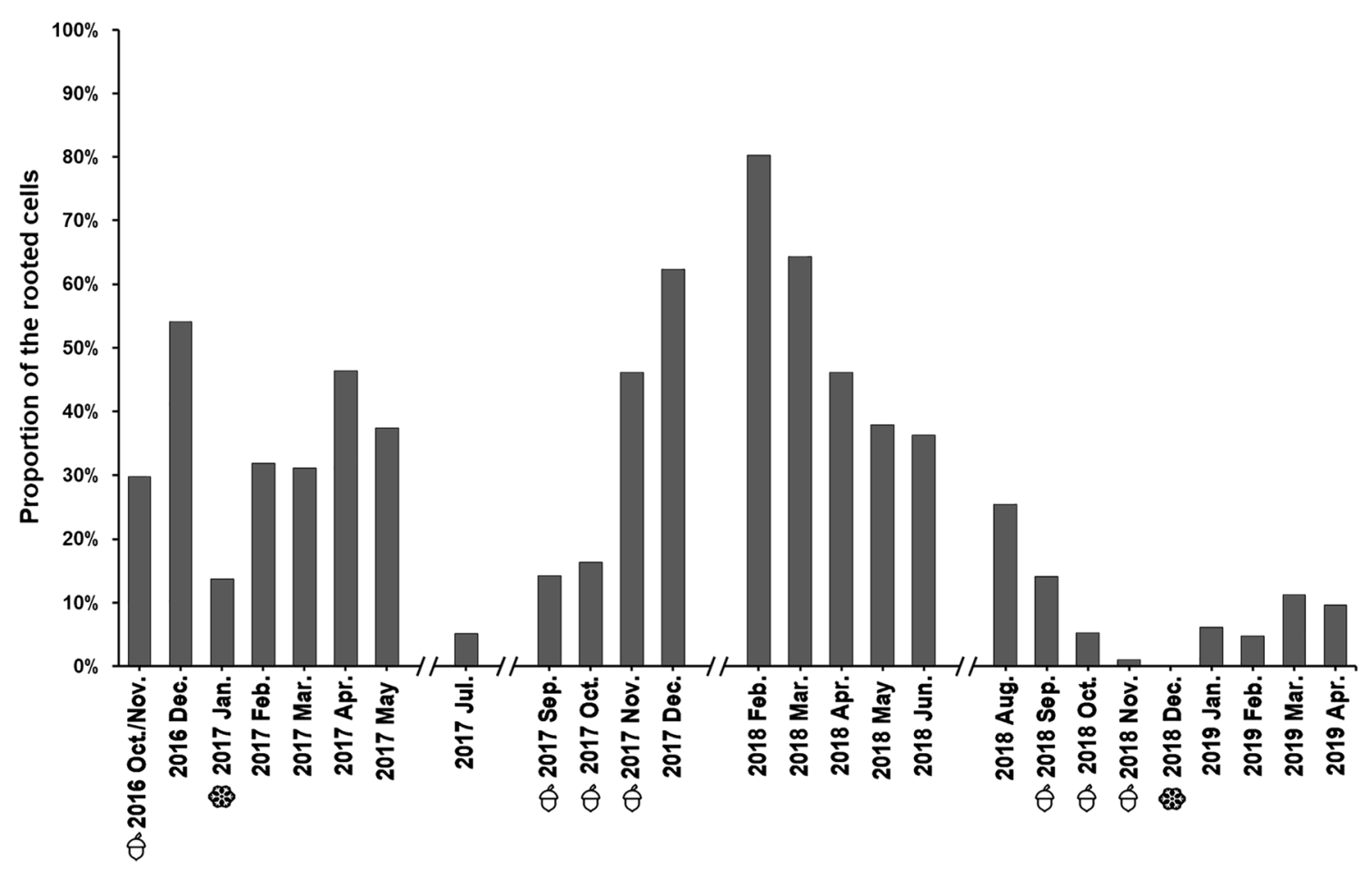

Fig. 3 Proportion of the disturbed and undisturbed cells by rooting during the study interval. Acorn symbols indicate the acorn fall periods, while snowflake symbols indicate when the study site was cov- ered by snow during the sampling. The breaks on the horizontal axis refer to gaps in data collection

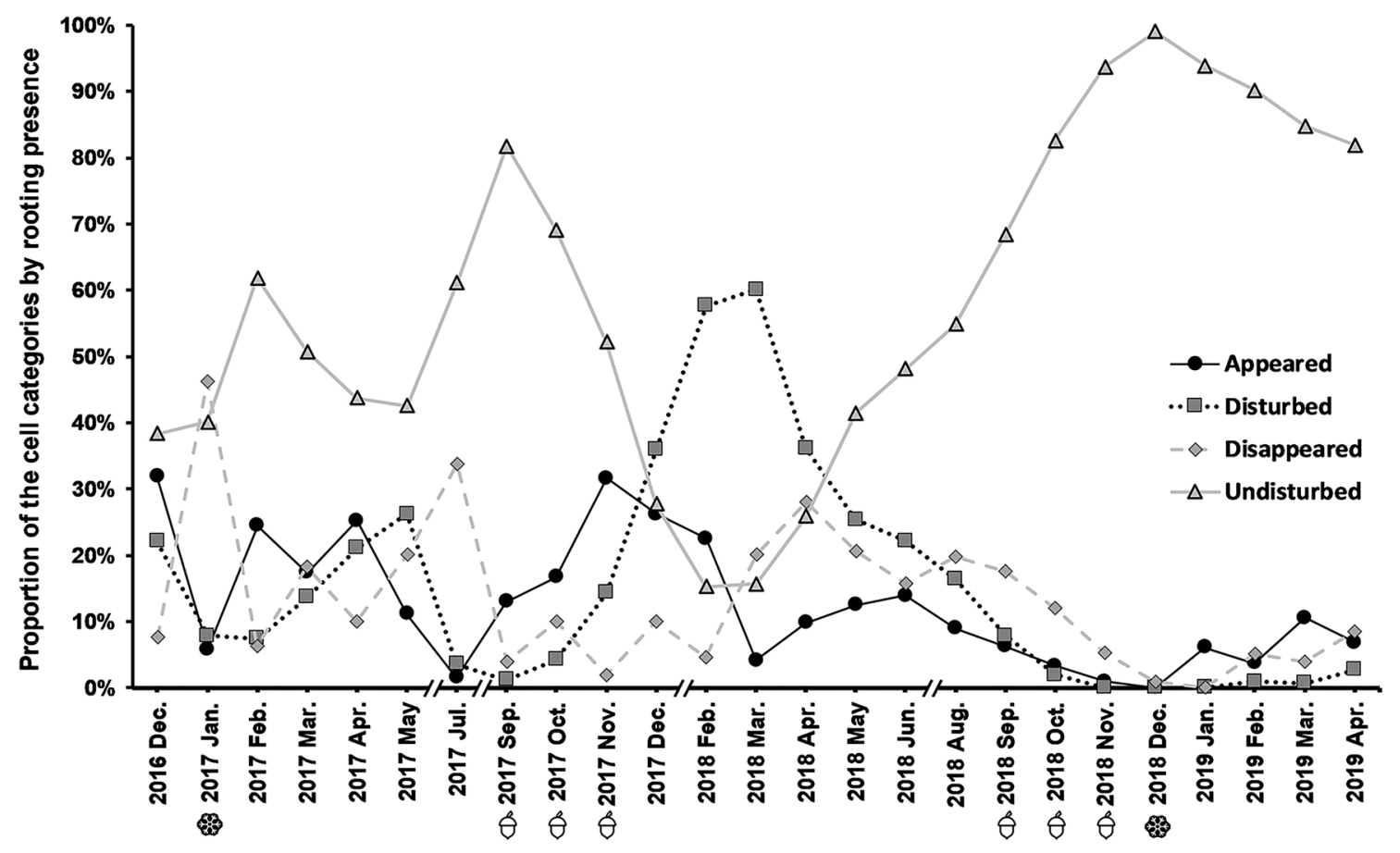

Fig. 4 Spatiotemporal dynamics of rooting disturbance on the study site. Acorn symbols indicate the acorn fall periods, while snowflake symbols indicate when the study site was covered by snow during the sampling. The breaks on the horizontal axis refer to gaps in data collection 
cells than in the acorn-rich periods of the two mast years $(\mathrm{KW}=8.27, p<0.05$; Dunn's post hoc test $p<0.05$ ). Also, in the 2018-2019 acorn-rich period there were significantly fewer "disturbed" cells than in 2017-2018 (KW=13.04, $p=0.0015$; Dunn's post hoc test: $p=0.002$ ) and there were more "undisturbed" cells than in the other acorn-rich periods $(\mathrm{KW}=12.62, p=0.0018$; Dunn's post hoc test: $p<0.05)$.

Similarly to this, if we compare the acorn-rich and acornweak periods of the first two masting years, the proportion of the "appeared" cells was higher in the acorn-rich periods $(U=16.5, p<0.05)$, while the proportion of the "undisturbed" cells was higher in the acorn-weak periods $(U=14.5, p<0.05)$.

\section{Temporal pattern of disturbance intensity in the wild boar rooted cells}

The average proportions of different kinds of the main disturbance types throughout the study are as follows: LD: $71.75 \pm 33.04 \%$, USD: $12.84 \pm 14.68 \%$, DSD: $10.72 \pm 18.46 \%$ and between 0.2 and $2.08 \%$ for the cells that were affected jointly by different rooting intensities, respectively (Fig. 5). The proportion of LD was significantly higher than that of all the other intensity types $(\mathrm{KW}=85.04$, $p<0.001$; Dunn's post hoc test: $p<0.001$ ). Moreover, the proportion of USD was also statistically higher than the values of three combined categories (LD + DSD; USD + DSD; $\mathrm{LD}+\mathrm{USD}+\mathrm{DSD}$ ) (Dunn's post hoc test $p<0.05$ ).

During the acorn fall period, the only statistical difference was between the LD (mean \pm SD:69.58 $\pm 37.98 \%$; Mdn: $80.86 \%$ ) and three of the more intense combined types (LD + DSD; USD + DSD; LD + USD + DSD; Mdn: $0.00 \%$ for all $)(\mathrm{KW}=24.94, p<0.001$; Dunn's post hoc test: $p<0.05$ ).

Throughout the acorn-rich periods, the proportion of the LD area (mean \pm SD: $85.36 \pm 19.94 \%$; Mdn: $94.18 \%$ ) was higher than in the case of any other types $(\mathrm{KW}=68.11$, $p<0.001$; Dunn's post hoc test: $p<0.05$ ). In the acornweak period, only the LD + USD + DSD (mean \pm SD: $0.28 \pm 0.59 \%$; Mdn: $0.00 \%$ ) category was smaller than all the main categories $(\mathrm{KW}=29.07, p<0.001$; Dunn's post hoc test: $p<0.05)$ and the LD+DSD (mean \pm SD: $0.97 \pm 1.63 \%$; Mdn: 0.00) was different from the USD (Dunn's post hoc test: $p<0.05)$.

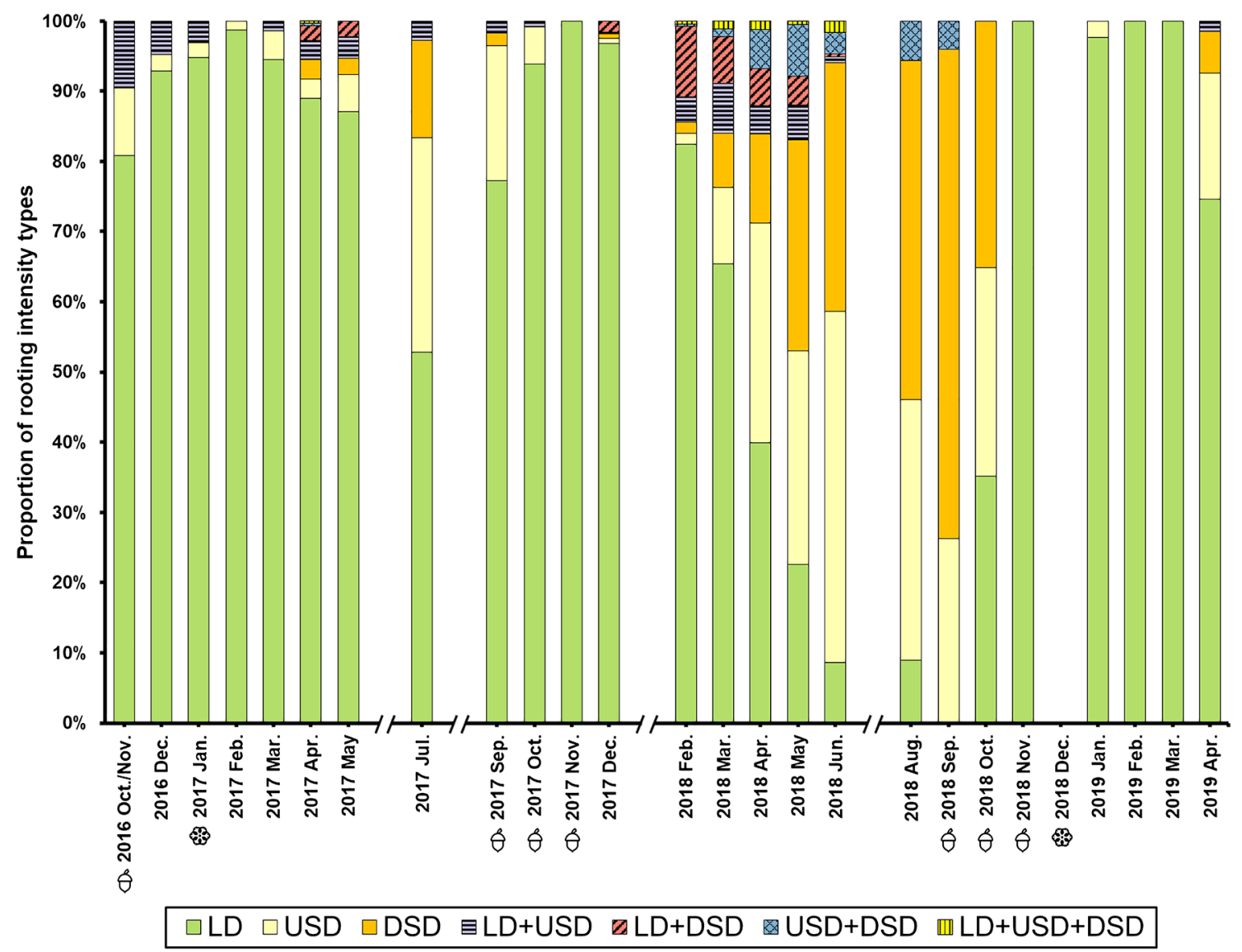

Fig. 5 Proportion of rooting intensity types during the study interval. Acorn symbols indicate the acorn fall periods, while snowflake symbols indicate when the study site was covered by snow during the sampling. The breaks on the horizontal axis refer to gaps in data collection 
The proportion of different rooting intensity types did not show any significant differences in inter-annual comparisons of the acorn-rich periods (Kruskal-Wallis tests: $p>0.05$ ).

\section{The interplay between the acorn density and the rooting intensity}

The result of the acorn density categorization is shown in Table 1. In the first two mast periods of the study, we were able to categorize the acorn density into three categories, while in the last non-mast period we were only able to categorize it into two classes (except 2018 October).

Both, in the acorn fall and non-fall period there was a significant relationship between the acorn density and the intensity of the rooting (fall period: $\mathrm{M}-\mathrm{L} X^{2}=22.49, d f=6$, $p<0.001$; non-fall period: Pearson $X^{2}=92.61, d f=6$, $p<0.001$ ), meaning that the acorn density varied along the differently rooted areas.
During the acorn fall period, when there was no rooting in a cell ("undisturbed"), the proportion of the upper acorn density category was the highest (15.93\%). But towards the more intensive rooting categories this proportion decreased and even missed from most of deeper soil disturbed cells. The proportion of the middle acorn density was the highest when there was litter disturbance $(17.42 \%)$.

But if we examine the acorn fall periods separately, significant relationship was found only in the last, non-mast acorn fall period between the acorn density and the intensity of the rooting (M-L $\left.X^{2}=14.47, d f=6, p=0.025\right)$. Moreover, cells with deeper soil disturbances were also only found in this period, but all with lower acorn density. Higher acorn density categories only occurred in the undisturbed and litter disturbed cells (upper acorn density: $20.19 \%$ and $25 \%$; middle acorn density: $3.11 \%$ and $0 \%$, respectively). On the contrary, in the first two-masting-acorn fall periods no

Table 1 Acorn density categories

\begin{tabular}{|c|c|c|c|c|c|c|c|c|}
\hline & $\mathrm{GVF}^{\mathrm{b}}$ & $\begin{array}{l}\text { Lower acorn } \\
\text { density class }\end{array}$ & $\begin{array}{l}\text { Middle acorn } \\
\text { density class }\end{array}$ & $\begin{array}{l}\text { Upper acorn } \\
\text { density class } \\
\text { Lower-upper }\end{array}$ & Lower $(n)$ & Middle $(n)$ & Upper $(n)$ & All $(n)$ \\
\hline $2016 \mathrm{Sep} / \mathrm{Nov}$ & 0.77 & $0-5$ & $6-14$ & $18-49$ & 84 & 24 & 14 & 122 \\
\hline 2016 December & 0.76 & $0-3$ & $4-11$ & $12-139$ & 79 & 22 & 17 & 118 \\
\hline 2017 January & 0.74 & $0-1$ & $2-6$ & $7-23$ & 73 & 35 & 10 & 118 \\
\hline 2017 February & 0.76 & $0-3$ & $4-10$ & $14-32$ & 78 & 31 & 9 & 118 \\
\hline 2017 March & 0.80 & $0-3$ & $4-10$ & $13-26$ & 80 & 33 & 5 & 118 \\
\hline 2017 April & 0.75 & $0-0$ & $1-3$ & $4-30$ & 69 & 40 & 9 & 118 \\
\hline 2017 September & 0.74 & $0-8$ & $9-28$ & $39-121$ & 48 & 13 & 10 & 71 \\
\hline 2017 October & 0.76 & $0-10$ & $11-32$ & $33-64$ & 76 & 34 & 8 & 118 \\
\hline 2017 November & 0.71 & $0-11$ & $12-27$ & $28-77$ & 86 & 22 & 10 & 118 \\
\hline 2017 December & 0.71 & $0-2$ & $3-10$ & $11-21$ & 63 & 45 & 10 & 118 \\
\hline 2018 February & 0.77 & $0-2$ & $3-6$ & $8-20$ & 91 & 23 & 4 & 118 \\
\hline 2018 March & 0.79 & $0-1$ & $2-5$ & $6-15$ & 63 & 39 & 16 & 118 \\
\hline 2018 April & 0.75 & $0-1$ & $2-3$ & $4-9$ & 94 & 17 & 7 & 118 \\
\hline 2018 May & ND & 0 & ND-ND & $1-20$ & 106 & ND & 12 & 118 \\
\hline 2018 June & ND & 0 & ND-ND & $1-8$ & 109 & ND & 9 & 118 \\
\hline 2018 August & ND & 0 & ND-ND & $1-5$ & 113 & ND & 5 & 118 \\
\hline 2018 September & $N D$ & 0 & $N D-N D$ & $1-7$ & 107 & $N D$ & 11 & 118 \\
\hline 2018 October & 0.85 & $0-1$ & $2-3$ & $5-28$ & 82 & 10 & 26 & 118 \\
\hline 2018 November & $N D$ & 0 & $N D-N D$ & $1-21$ & 89 & $N D$ & 29 & 118 \\
\hline 2018 December & ND & 0 & ND-ND & $1-2$ & 112 & ND & 6 & 118 \\
\hline 2019 January & ND & 0 & ND-ND & $1-3$ & 110 & ND & 8 & 118 \\
\hline 2019 February & ND & 0 & ND-ND & $1-6$ & 103 & ND & 15 & 118 \\
\hline 2019 March & ND & 0 & ND-ND & $1-4$ & 108 & ND & 10 & 118 \\
\hline 2019 April & ND & 0 & ND-ND & 1 & 117 & ND & 1 & 118 \\
\hline
\end{tabular}

Italics indicate the acorn fall periods, while snowflake symbols indicate when the study site was covered by snow during the sampling

${ }^{\text {a}}$ Determined by ROUT method

${ }^{b}$ Determined by Jenks optimization method; GVF: "goodness of variance fit" in Jenks optimization, 0 means worst fit, 1 means perfect fit; ND: "no data" 
significant relationship was revealed (2016: M-L $X^{2}=2.89$, $d f=4, p=0.58 ; 2017$ : M-L $\left.X^{2}=5.99, d f=4, p=0.19\right)$.

In the non-fall period, despite the significant difference among the cells of different rooting intensities, rooting impact did not cause so obvious decrease in the lower acorn supply (Fig. 6a, b).

\section{Discussion}

This study indicates that wild boar is a powerful ecosystem engineer species which can strongly influence its habitat due to its most peculiar attribute the rooting behaviour (Genov 1981; Massei and Genov 2004; Barrios-Garcia and Ballari 2012; Sandom et al. 2013; Genov et al. 2017; Sondej and Kwiatkowska-Falińska 2017). Approximately $90 \%$ of the study area was rooted at least once-which is much more than what Welander (2000) found in another deciduous forest-and only about $10 \%$ of the forest was exempt from rooting. Our study showed that wild boar rooting affected on average about $30 \%$ of the forest at a given time consisting of $15 \%$ of newly (within 1 month) created surface disturbances. Previous studies have already shown that wild boar can affect the soil nutrient cycle (Singer et al. 1984; Wirthner et al. 2012; Don et al. 2019) or the cover and the diversity of the forest herbaceous layer (Brunet et al. 2016; Sondej and Kwiatkowska-Falińska 2017) and of course the regeneration of the oak species (Groot Bruinderink and Hazebroek 1996; Gómez and Hódar 2008; van Ginkel et al. 2013; Perea and Gil 2014; Kamler et al. 2016; Zeman et al. 2016; Bongi et al. 2017).
We expected that the wild boars would root most actively during the acorn fall, even so their activity showed some lagging and they only became really active towards the end of the fall period. Moreover, their most active phases were usually during the winter and spring months-quite similar to the findings by Sandom et al. (2013) - but only if there was an adequate mast before. Though, the only time when we did not find any rooting was in winter (2018 December), these could have been due to the fresh snow cover and the lack of mast. Our studies showed that the rooting behaviour of the wild boar is fundamentally driven by the acorn density. During the first two autumns in our study, the oaks were masting, unlike in the last one. This phenomenon essentially determined the characteristics of the study area for the next few months from the perspective of available food source and therefore wild boar rooting. It also presumably affects the population density of the wild boars in the area, because oak acorns are the main nutrition source for the species starting from autumn, affecting their home range size and population dynamics (Bieber and Ruf 2005; Cutini et al. 2013; Morelle et al. 2015; Zeman et al. 2016; Bisi et al. 2018). It was also represented well in this study by the lower range of the rooted ground surface in the non-mast year, reflecting the lower degree of use of this habitat.

The intensity of the rooting also showed similar patterns; wild boars tended to root mainly the litter layer, and then rooting became more intensive during the summer months when the acorns hardly occur. The main target of this more intensive rooting was therefore probably not the acorns but more likely earthworms, plant roots or bulbs (a)

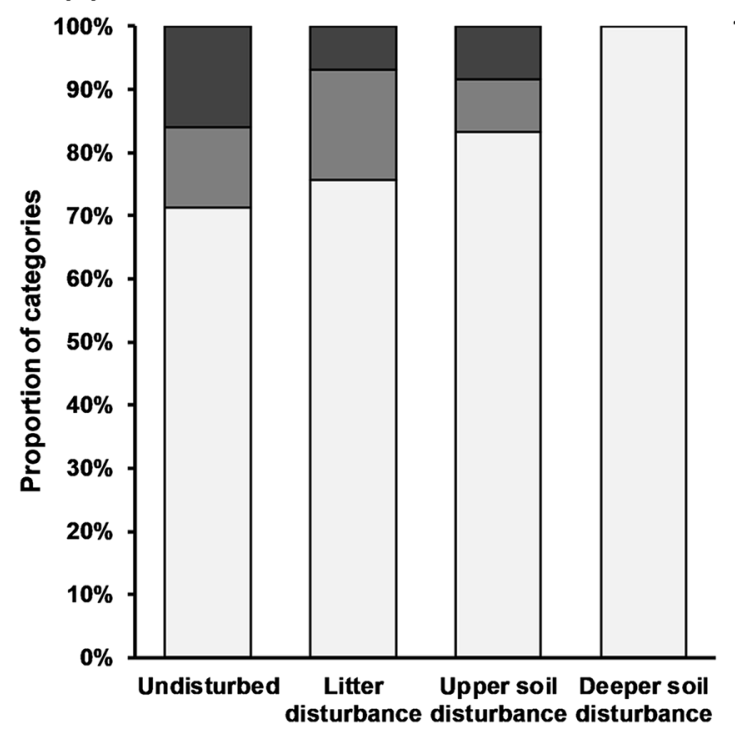

(b)

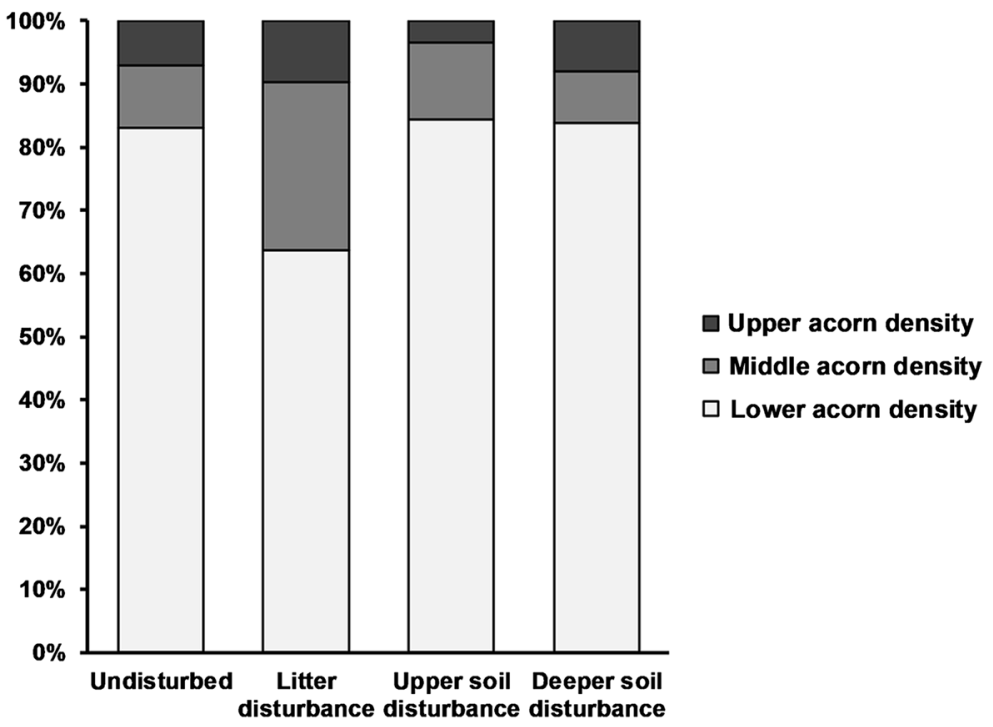

Fig. 6 Proportion of the acorn density categories in cells of different rooting intensities, $\mathbf{a}$ during the acorn fall period, $\mathbf{b}$ during the non-fall period 
(Welander 2000; Baubet et al. 2003, 2004; Massei and Genov 2004; Ballari and Barrios-García 2014).

Acorn density quickly decreased after the fall period. Therefore, we supposed a parallel decrease in the presence of rooting in the area. Even so we could not reveal any significant difference in the proportion of rooted cells between fall and non-fall periods. But we found that acorn density was lower in cells where rooting of different intensities was registered than in undisturbed cells. Areas with the most intensive rooting only had sampling points with lower acorn density, while sampling points with upper acorn density occurred in the largest proportion mainly in the undisturbed areas. The less intense litter disturbances can slightly diminish the acorn supply, but more intensive rooting will abolish the acorns. From the other side of this relationship, only in the third-nonmast-year we found deep rooting of the highest intensity, causing the entire depletion of acorns from these patches. All these suggest that wild boars likely show a less extent, but patchier rooting behaviour when searching for food through the acorn fall, and the proportion of acorns consumed by wild boar will be higher in the case of lower acorn density.

Wild boars are substantial seed predators (Groot Bruinderink and Hazebroek 1996; Cutini et al. 2013; van Ginkel et al. 2013; Kamler et al. 2016), and therefore they have a significant effect on the acorn density. Occasionally, they can even consume almost all of the produced acorns and therefore can impede the regeneration of the oaks (Cutini et al. 2013; van Ginkel et al. 2013; Zeman et al. 2016). Based on this study, it is still undecidable if the impact of the wild boars in the studied forest was sufficiently large to impede the oak regeneration completely. But we can assume that seed predators and principally wild boars had a great effect on acorn density and moreover the whole forest, by rooting almost the whole studied area at least once.

However, the effects of the wild boar rooting are not inherently negative for the forest; on the contrary, it can be a quite important function in an ecosystem. Rooting at an adequate level can provide an intermediate disturbance leading to an increase in biodiversity (Shea et al. 2004). Although the tolerable level of disturbance depends on the purpose of forest management. Even moderate wild boar rooting might be undesirable in commercial forests and can decelerate regeneration significantly, while in forests where the natural processes are more prioritized, a slower, patchier regeneration can also be sufficient. We believe that this methodology can help us to get a greater understanding of the effects and the dynamics of the wild boar rooting in temperate oak forests and to identify the favourable patterns of wild boar disturbances.

\section{Conclusions}

Understanding the spatiotemporal dynamics and effects of the wild boar rooting in oak forests is essential to manage the occurring conflicts in the future that can emerge with the rising wild boar populations. Our results suggest that wild boar can have a significant effect on oak regeneration, and the masting of the oaks has a crucial role in their rooting dynamics. We suggest the development of a predictive system for wild boar impacts (by using data on mast trees, acorn production and spatiotemporal characteristics of rooting site selection of wild boar) which can help the managers to identify when and where to expect large proportions of rooting and problems in the regeneration. This system can help intervene in a more efficient way, e.g. through proactive local population regulation of wild boar or fencing of sensitive regeneration patches.

Acknowledgements Open access funding provided by Szent István University (SZIE). We are grateful to Péter Szabó for making our investigations possible on the area. Ábris Nagy and Thabang Rainett Teffo improved the English language of the manuscript. Dóra Hegedús assisted in editing the figures. Our research was supported by the Doctoral School of Biology of Eötvös Loránd University.

Open Access This article is licensed under a Creative Commons Attribution 4.0 International License, which permits use, sharing, adaptation, distribution and reproduction in any medium or format, as long as you give appropriate credit to the original author(s) and the source, provide a link to the Creative Commons licence, and indicate if changes were made. The images or other third party material in this article are included in the article's Creative Commons licence, unless indicated otherwise in a credit line to the material. If material is not included in the article's Creative Commons licence and your intended use is not permitted by statutory regulation or exceeds the permitted use, you will need to obtain permission directly from the copyright holder. To view a copy of this licence, visit http://creativecommons.org/licenses/by/4.0/.

\section{References}

Ballari SA, Barrios-García MN (2014) A review of wild boar Sus scrofa diet and factors affecting food selection in native and introduced ranges. Mamm Rev 44:124-134. https://doi. org/10.1111/mam.12015

Barrios-Garcia MN, Ballari SA (2012) Impact of wild boar (Sus scrofa) in its introduced and native range: a review. Biol Invasions 14:2283-2300. https://doi.org/10.1007/s 1053 0-012-0229-6

Baubet E, Ropert-Coudert Y, Brandt S (2003) Seasonal and annual variations in earthworm consumption by wild boar (Sus scrofa scrofa L.). Wildl Res 30:179-186. https://doi.org/10.1071/WR00113

Baubet E, Bonenfant C, Brandt S (2004) Diet of the wild boar in the French Alps. Galemys 16:101-113

Bieber C, Ruf T (2005) Population dynamics in wild boar Sus scrofa: ecology, elasticity of growth rate and implications for the management of pulsed resource consumers. J Appl Ecol 42:1203-1213. https://doi.org/10.1111/j.1365-2664.2005.01094.x 
Bisi F, Chirichella R, Chianucci F et al (2018) Climate, tree masting and spatial behaviour in wild boar (Sus scrofa L.): insight from a long-term study. Ann For Sci 75:46. https://doi.org/10.1007/ s13595-018-0726-6

Bobiec A, Jaszcz E, Wojtunik K (2011) Oak (Quercus robur L.) regeneration as a response to natural dynamics of stands in European hemiboreal zone. Eur J For Res 130:785-797. https://doi. org/10.1007/s10342-010-0471-3

Bogdziewicz M, Espelta JM, Muñoz A et al (2018) Effectiveness of predator satiation in masting oaks is negatively affected by conspecific density. Oecologia 186:983-993. https://doi.org/10.1007/ s00442-018-4069-7

Bongi P, Tomaselli M, Petraglia A et al (2017) Wild boar impact on forest regeneration in the northern Apennines (Italy). For Ecol Manag 391:230-238. https://doi.org/10.1016/j.foreco.2017.02.028

Brudvig LA (2008) Large-scale experimentation and oak regeneration. For Ecol Manag 255:3017-3018. https://doi.org/10.1016/j. foreco.2008.02.006

Brunet J, Hedwall PO, Holmström E, Wahlgren E (2016) Disturbance of the herbaceous layer after invasion of an eutrophic temperate forest by wild boar. Nord J Bot 34:120-128. https://doi. org/10.1111/njb.01010

Csányi S, Márton M, Kovács V et al (2018) Vadgazdálkodási Adattár-2017/2018. vadászati év. Országos Vadgazdálkodási Adattár, Gödöllő, 52 pp

Cutini A, Chianucci F, Chirichella R et al (2013) Mast seeding in deciduous forests of the northern Apennines (Italy) and its influence on wild boar population dynamics. Ann For Sci 70:493502. https://doi.org/10.1007/s13595-013-0282-z

Dardaillon M (1986) Seasonal variations in habitat selection and spatial distribution of wild boar (Sus scrofa) in the Camargue, Southern France. Behav Processes 13:251-268. https://doi. org/10.1016/0376-6357(86)90088-4

de Rigo D, Enescu CM, Houston Durrant T, Caudullo G (2016) Quercus cerris in Europe: distribution, habitat, usage and threats. In: San-Miguel-Ayanz J, de Rigo D, Caudullo G, Houston Durrant T, Mauri A (eds) European Atlas of Forest Tree species. European Commission, Luxembourg

Don A, Hagen C, Grüneberg E, Vos C (2019) Bioturbation by wild boar increases the stability of forest soil carbon. Biogeosciences. https://doi.org/10.5194/bg-2019-113

Eaton E, Caudullo G, Oliveira S, de Rigo D (2016) Quercus robur and Quercus petraea in Europe: distribution, habitat, usage and threats. In: San-Miguel-Ayanz J, de Rigo D, Caudullo G, Houston Durrant T, Mauri A (eds) European Atlas of Forest Tree species. European Commission, Luxembourg

Genov P (1981) Food composition of wild boar in north-eastern and western Poland. Acta Theriol (Warsz) 26:185-205. https://doi. org/10.4098/AT.arch.81-16

Genov PV, Focardi S, Morimando F et al (2017) Ecological impact of wild boar in natural ecosystems. In: Melletti M, Meijaard E (eds) Ecology, conservation and management of wild Pigs and Peccaries. Cambridge University Press, Cambridge, pp 404-419

Gómez JM, Hódar JA (2008) Wild boars (Sus scrofa) affect the recruitment rate and spatial distribution of holm oak (Quercus ilex). For Ecol Manag 256:1384-1389. https://doi.org/10.1016/j. foreco.2008.06.045

Groot Bruinderink GWTA, Hazebroek E (1996) Wild boar (Sus scrofa scrofa L.) rooting and forest regeneration on podzolic soils in the Netherlands. For Ecol Manag 88:71-80. https://doi. org/10.1016/S0378-1127(96)03811-X

Groot Bruinderink GWTA, Hazebroek E, Van Der Voot H (1994) Diet and condition of wild boar, Sus scrofa scrofa, without supplementary feeding. J Zool 233:631-648. https://doi. org/10.1111/j.1469-7998.1994.tb05370.x
Haas JP, Heske EJ (2005) experimental study of the effects of mammalian acorn predators on red oak acorn survival and germination. J Mammal 86:1015-1021. https://doi.org/10.1644/15451542(2005)86\%5b1015:esoteo\%5d2.0.co;2

Horčičková E, Brůna J, Vojta J (2019) Wild boar (Sus scrofa) increases species diversity of semidry grassland: field experiment with simulated soil disturbances. Ecol Evol 9:2765-2774. https://doi.org/10.1002/ece3.4950

Jenks GF (1967) The data model concept in statistical mapping. Int Yearb Cartogr 7:186-190

Kamler J, Dobrovolný L, Drimaj J et al (2016) The impact of seed predation and browsing on natural sessile oak regeneration under different light conditions in an over-aged coppice stand. IForest 9:569-576. https://doi.org/10.3832/ifor1835-009

Katona K, Heltai M (2018) A vaddisznó táplálék-összetételének és táplálkozási sajátságainak szakirodalmi áttekintése. Tájökológiai Lapok 16:65-74

Katona K, Kiss M, Bleier N et al (2013) Ungulate browsing shapes climate change impacts on forest biodiversity in Hungary. Biodivers Conserv 22:1167-1180. https://doi.org/10.1007/s1053 1-013-0490-8

Leonardsson J, Löf M, Götmark F (2015) Exclosures can favour natural regeneration of oak after conservation-oriented thinning in mixed forests in Sweden: a 10-year study. For Ecol Manag 354:1-9. https ://doi.org/10.1016/j.foreco.2015.07.004

Massei G, Genov PV (2004) The environmental impact of wild boar. Galemys 16:135-145

Massei G, Kindberg J, Licoppe A et al (2015) Wild boar populations up, numbers of hunters down? A review of trends and implications for Europe. Pest Manag Sci 71:492-500. https://doi.org/10.1002/ ps.3965

Morelle K, Podgórski T, Prévot C et al (2015) Towards understanding wild boar Sus scrofa movement: a synthetic movement ecology approach. Mamm Rev 45:15-29. https://doi.org/10.1111/ mam. 12028

Motulsky HJ, Brown RE (2006) Detecting outliers when fitting data with nonlinear regression - a new method based on robust nonlinear regression and the false discovery rate. BMC Bioinformatics 7:1-20. https://doi.org/10.1186/1471-2105-7-123

Mráz B, Katona K (2014) Állati magterjesztés, kiemelten a vaddisznó (Sus scrofa) szerepe a növényzeti mintázatok kialakulásábanáttekintés. Gyepgazdálkodási Közlemények 1-2:39-47

Nováková P, Štípek K (2011) Effect of diet supply and climatic conditions on population dynamics of the wild boar (Sus scrofa) in the Křivoklát region (Central Bohemia, Czech Republic). Sci Agric Bohem 1:24-30

Perea R, Gil L (2014) Tree regeneration under high levels of wild ungulates: the use of chemically vs. physically-defended shrubs. For Ecol Manag 312:47-54. https://doi.org/10.1016/j.forec o.2013.10.022

Ramirez JI, Jansen PA, Poorter L (2018) Effects of wild ungulates on the regeneration, structure and functioning of temperate forests: a semi-quantitative review. For Ecol Manag 424:406-419. https ://doi.org/10.1016/J.FORECO.2018.05.016

Sandom CJ, Hughes J, Macdonald DW (2013) Rewilding the Scottish Highlands: do wild boar, Sus scrofa, use a suitable foraging strategy to be effective ecosystem engineers? Restor Ecol 21:336-343. https://doi.org/10.1111/j.1526-100X.2012.00903.x

Schelhaas M-J, Nabuurs G-J, Cullmann DA et al (2012) Climate change may cause severe loss in the economic value of European forest land. Nat Clim Chang 3:203-207. https://doi.org/10.1038/ nclimate 1687

Shea K, Roxburgh SH, Rauschert ESJ (2004) Moving from pattern to process: coexistence mechanisms under intermediate disturbance regimes. Ecol Lett 7:491-508. https://doi.org/10.111 1/j.1461-0248.2004.00600.x 
Singer FJ, Swank WT, Clebsch EEC (1984) Effects of wild pig rooting in a deciduous forest. J Wildl Manag 48:464-473. https://doi. org/10.2307/3801179

Sondej I, Kwiatkowska-Falińska AJ (2017) Effects of wild boar (Sus scrofa L.) rooting on seedling emergence in Białowieża Forest. Pol J Ecol 65:380-389. https://doi.org/10.3161/15052249PJE2017 .65 .4 .007

Sork VL (1993) Evolutionary ecology of mast-seeding in temperate and tropical oaks (Quercus spp.). Vegetatio 107-108:133-147. https://doi.org/10.1007/BF00052217

van Ginkel HAL, Kuijper DPJ, Churski M et al (2013) Safe for saplings not safe for seeds: Quercus robur recruitment in relation to coarse woody debris in Białowieża Primeval Forest, Poland. For Ecol Manag 304:73-79. https://doi.org/10.1016/j.foreco.2013.04.037
Welander J (2000) Spatial and temporal dynamics of wild boar (Sus scrofa) rooting in a mosaic landscape. J Zool 252:263-271. https ://doi.org/10.1017/S0952836900009997

Wirthner S, Schütz M, Page-Dumroese DS et al (2012) Do changes in soil properties after rooting by wild boars (Sus scrofa) affect understory vegetation in Swiss hardwood forests? Can J For Res 42:585-592. https://doi.org/10.1139/x2012-013

Zeman J, Hrbek J, Drimaj J et al (2016) Wild boar impact to the natural regeneration of oak and acorn importance in its diet. Acta Univ Agric Silvic Mendel Brun 64:579-585. https://doi.org/10.11118 /actaun201664020579

Publisher's Note Springer Nature remains neutral with regard to jurisdictional claims in published maps and institutional affiliations. 